\title{
Human Papillomavirus 16 E7 Peptide
}

National Cancer Institute

\section{Source}

National Cancer Institute. Human Papillomavirus 16 E7 Peptide. NCI Thesaurus. Code C25758.

A peptide vaccine consisting of amino acids 12 through 20 of the viral oncoprotein human papillomavirus (HPV) 16 E7. Vaccination with HPV-16 E7 peptide may stimulate the host immune system to mount a cytotoxic $\mathrm{T}$ lymphocyte (CT L) response against tumor cells positive for HPV-16 E7, resulting in decreased tumor growth. HPV-16 infection is tumorigenic and highly associated with cervical cancer. ( $\mathrm{NCl04)}$ 